\title{
1. The Keynesian liquidity trap: an Austrian critique ${ }^{1}$ \\ Peter Boettke and Patrick Newman
}

\section{INTRODUCTION}

Few economists can deny the influence of John Maynard Keynes and his The General Theory of Employment, Interest, and Money (1936). As Mark Blaug put it: "The Keynesian Revolution is one of the most remarkable episodes in the entire history of economic thought; never before had the economics profession been won over so rapidly and so massively to a new economic theory, and nor has it since." "Within the space of about a decade, 1936-1946," he continues, "the vast majority of economists throughout the Western world were converted to the Keynesian way of thinking" (Blaug 2010 [1997], 642). In short, Keynes forever changed the course of economic thinking and policy. To some, particularly the younger economists, The General Theory was a blessing. Paul Samuelson described the sensation of both being an economist when The General Theory came out and also to be younger than 35 as "Bliss it was in that dawn to be alive, but to be young was very heaven." Samuelson considered the book, although poorly written and confusing, to be the "work of a genius" (Samuelson 1947, 145-9).

However, some of the older economists over 50, as Samuelson noted, were not so easily swayed. Frank Knight had argued in his review of The General Theory that "Mr. Keynes's own doctrines are, as he would proudly admit, among the notorious fallacies to combat which has been considered a main function of the teaching of economics" (Knight 2009 [1937], 69). And in his Presidential Address to the American Economic Association (AEA) in 1951, Knight criticized the Keynesian Revolution for dragging economic thought "well back into the dark age" (Knight 1951, 2). In an early review of the book Henry Simons claimed that "Mr. Keynes proceeds to espouse the cause of an army of cranks and heretics simply on the grounds that their schemes or ideas would incidentally have involved or suggested mitigation of the deflationary tendencies in the economy." And he warned that Keynes and The General Theory might very well 
become "the academic idol of our worst cranks and charlatans" (Simons 1936, 1017). ${ }^{2}$ To Knight, Simons, and other critics they saw The General Theory as overturning the basic tenets of economic theorizing and, most importantly, the self-correcting power of markets. ${ }^{3}$

However, the critics did not succeed in forestalling the Keynesian Revolution as Keynesian ideas came to dominate the economics profession from the late 1930s to the late 1970s, when the New Classical Macroeconomics represented a challenge to the hegemonic paradigm of Keynesianism. There are two important qualifiers to this familiar narrative. First, while New Classical Macroeconomics offered a theoretical challenge and raised policy doubts about the effectiveness of traditional Keynesian demand management policies, its influence was always restricted to pure academic research and not to the practical policy world. In the practical policy world, the basic Keynesian policy tools were employed, and what oscillated was either a "conservative" Keynesianism or a "liberal" Keynesianism; but macroeconomic demand management and fine-tuning policies never disappeared in western democracies. And, second, even given the impact of New Classical Macroeconomics among elite researchers in academic economics, there was still a very strong contingency of elite economists who maintained the core Keynesian intellectual agenda. As James Tobin announced in a wonderful essay - "How dead is Keynes?", published right in the middle of the so-called New Classical Revolution (1977) - Keynes was far from dead and was in fact very much alive and kicking. A close look at modern economics will reveal that Keynesianism never left center stage in economic thought and certainly never in policy circles, as not just older economists, such as Tobin, but members of the generation after him, such as Stanley Fisher, continued to have an oversized influence and one that impacted the leading economic thinkers and economic policy makers, such as Joseph Stiglitz and Lawrence Summers - both of whom have cycled in and out of Ivy League academic posts and high-level economic policy positions since the 1970s. In a profound sense, the Keynesian Revolution never ended.

What exactly were the main tenets of the Keynesian Revolution? Aside from the theory of underemployment equilibrium, in which Keynes argued that there could be a static state with involuntary unemployment even with flexible prices (that is, that wage cuts would not reduce unemployment), most notably there is his theory of liquidity preference and the related idea of a "liquidity trap." 4 Seeking to reject the classical theory, Keynes explained the rate of interest as being determined by the supply of money and individuals' demand for money, also known as their liquidity preference. Individuals' speculative demand for money was a decreasing function of the interest rate. Keynes argued that in some scenarios, most 
notably in depressions, at a certain rate of interest the demand to hold money would be infinitely elastic and market forces could not be relied upon to lower interest rates and stimulate investment to get the economy out of the depression. This is because individuals will just hoard their money and not spend it on bonds because they believe their price will fall in the future (that is, that interest rates will rise). In this situation monetary policy would be ineffective at combating depressions because it could not lower interest rates to boost investment spending, and expansionary fiscal policy would be the only remedy. Monetary policy would be like "pushing on a string" but aggressive fiscal policy could stimulate aggregate demand. This situation is known as a liquidity trap, and it constitutes one of the fundamental distinctive features of Keynesianism in contrast to Monetarism, which champions expansionary monetary policy during a depression. ${ }^{5}$ While previously considered a remote possibility extremely unlikely to occur, with the 1990s Japanese slump and the 2008 financial crisis, economists have argued that the liquidity trap theory is empirically relevant now (Krugman 2009 [1999]). The liquidity trap is a powerful argument not only against the idea that monetary policy is effective, but also that market forces unaided by government can work during a depression. How effective can the market be at reallocating resources and promoting a recovery if investors just hoard their money and do not spend it?

At an analytical level, it is our contention that the real opponents of Keynes are the Austrians, who belong to the school of thought that best champions the theory of a self-correcting market economy. As a result, the Austrian economists offer the starkest differences from Keynesians. Austrians were some of the first and most prominent to criticize Keynes and his economics, as started with Hayek $(2008[1931,1932])$ and through the Keynes-Hayek debates. To Hayek, Mises and Rothbard, the countercyclical policies embraced by Keynesians, as well as the Chicago School Monetarists, in order to combat downturns are generally seen as counterproductive because they stifle the reallocation process of resources that were poorly invested during the previous boom. ${ }^{6}$ However, does this argument apply in such scenarios where a liquidity trap exists? Can the market unaided by government involvement actually be expected to work in such a situation?

The present chapter argues that in such a scenario the market can be expected to work provided that it is allowed to work. This chapter provides critiques of the liquidity trap theory from an Austrian perspective. In doing so it will rely primarily on older Austrian writers, as the new Austrian macroeconomists such as Garrison (2006 [2001]) do not discuss the concept of the liquidity trap in their analyses. This is mainly due to the fact that most economists thought that the empirical possibility of a 
liquidity trap was very slim until recently. In addition, we also use older writers to show that these Austrian criticisms are not new and novel modern-day arguments against the Keynesian system, but rather old and fundamental critiques that were made back in the heyday of Keynesianism that went unnoticed. And the criticisms that were raised are as relevant as ever since the Keynesian liquidity trap has regained popularity in the Global Financial Crisis as an explanatory tool and guide for public policy. The main problem these authors note is that the Keynesian theory concentrates on the loan rate of interest, which is only subsidiary to the natural interest rate expressed in the price spread in the structure of production that is determined by time preferences and not liquidity preferences. Since the loan rate is a reflection of the natural rate, an expected rising loan rate means that the price spread in the economy is expected to rise (that is, factor prices will fall relative to the prices of the outputs they produce), which is a requisite for a market-based recovery. Provided that prices are allowed to fall freely and are not propped up by government intervention the liquidity trap roadblock poses no genuine threat for the free market economy. Only when prices are rigid and government intervention is pervasive does the phenomenon of a liquidity trap and hoarding money result in a stagnant economy.

This chapter is structured as follows. Section 2 presents a brief analysis of the Austrian theory of interest and shows both how it is determined by time preference and its coordinative role for entrepreneurial calculations. Section 3 describes the liquidity trap and critiques it with the aforementioned Austrian theory of interest, and section 4 concludes.

\section{AUSTRIAN INTEREST RATE THEORY}

Keynes famously argued that the interest rate is determined by liquidity preference, or the demand for money. Interest, according to Keynes, is the "reward for parting with liquidity" (Keynes 1964 [1936], 167). After deciding how much out of income to consume and not consume, which is determined by his propensity to consume, an individual then decides how much of his leftover funds he will invest in securities or keep in his cash balance, the latter of which is determined by his liquidity preference. Keynes splits liquidity preference and the demand for money into transactions demand, precautionary demand, and speculative demand. The first two are related to spending and are a function of real income. On the other hand, the speculative demand is a function of the interest rate, which represents the opportunity cost of holding money. At a higher interest rate there is a greater opportunity cost of holding money relative to investment, and 
correspondingly there will be a smaller quantity of money demanded since individuals will instead decide to buy securities with their funds. Therefore the speculative demand for money is a decreasing function of the interest rate and the demand curve slopes downwards. The interest rate equilibrates the supply and demand for money and the equilibrium rate is determined by their intersection (Keynes 1936, 166-74, 194-204; Modigliani 2009 [1944], 136-43). ${ }^{7}$ If the interest rate is above equilibrium, then there is an excess supply of money and individuals will buy bonds in order to reduce their cash balances. This pushes up the price of bonds, which decreases their yield (that is, the interest rate), which increases the quantity of money demanded until equilibrium is restored. The reverse occurs for an interest rate below equilibrium. Thus, increases and decreases in the money supply lead to excess supplies or demands for money, and correspondingly change the interest rate through buying and selling securities.

To the Austrians, this entire analysis of the interest rate is completely misplaced. In the first place, the demand for money is unrelated to the interest rate as the interest rate is not determined by liquidity preference but instead by time preference. Time preference is the premium on present consumption over future consumption, and is more generally described as the premium on present goods over future goods. The interest rate is the societal rate of time preference, or the specific premium on present goods over future goods. It is the premium on present money (money that can be spent on consumer goods for present consumption) over future money (money that is earned from investments for future consumption). In order to earn monetary interest an individual must supply present money for future money. The interest rate bears a strict relationship with the proportion of total money spent on consumption to total money spent on investment during a given period, as both are two sides of the same coin and are determined by time preferences. The proportion represents the degree of present consumption versus future consumption, whereas the interest rate represents the particular premium on present consumption over future consumption. A fall in time preferences is embodied in a fall in the consumption-investment proportion and a decline in the interest rate, and vice versa (Mises 2008 [1949], 529-30; Rothbard 2009 [1962], 400-404, 549, 860).

The unimportance of the demand for money to the interest rate can be seen in the above analysis. The reservation demand for money determines how much money an individual does not spend on either consumption or investment and instead keeps in his cash balance. On the other hand, time preferences determine the interest rate and the relative proportion between consumption and investment. An increase in the demand for money does not affect the interest rate if it does not change the 
relative consumption-investment proportion. An increase in the demand for money could also either increase or decrease the interest rate if the relative proportion is raised or lowered as well (Rothbard 1962, 773-6, 788-9; Rothbard 2008 [1963], 37-40).

In the second place, the interest rate is not simply the loan rate that is determined in either the money market (the supply and demand for money) or the loanable funds market (the supply and demand for loanable funds). Instead, the interest rate is the price spread between stages of production, and is sometimes described as the relative difference between the cumulative prices of consumer goods and the prices of producer goods that make them (Mises 1949, 521; Rothbard 1962, 371). It can be termed the natural rate because it is the interest that comes "naturally" by investing in production processes, as opposed to the loan, or contractual rate of interest that is fixed in the contract (Rothbard 1962, 441).

The natural rate is a monetary rate of interest and not the rate of interest that would exist under barter conditions. There is not a separate natural rate of interest for each "real" good that cannot be equilibrated. Instead, in the monetary economy, all present and future goods on the time market refer to present and future money, and so the rates of return are in terms of the same good (money) and can be equilibrated (Rothbard 1962, 375). Money is its own good and is not simply a "veil" that is added onto a barter economy (Mises 1949, 203, 414-15; Rothbard 1962, 235, 269-70). A unitary rate of interest that can be isolated could not exist in a barter economy (Mises 1990 [1932], 65). This point bears emphasizing because the natural rate of interest concept has been criticized on these grounds, particularly by Sraffa in the Sraffa-Hayek debate in the early 1930s (Skousen 2007 [1990], 49-51). While earlier Austrian expositions could be criticized using the faulty barter natural interest rate framework (for example, Mises 2006 [1928], 107-8), the modern Austrian monetary and interest theory is immune to this criticism.

At each stage of production businesses, or, more strictly, the capitalistentrepreneurs, either purchase or rent capital goods and land as well as hire labor. They then use these factors in a production process to produce goods that will be sold in the future. In long-run equilibrium the rate of return earned, or the price spread between the cumulative prices of factors of production and the products they produce, is the natural rate of interest. In such a static world the natural rate is equal to the pure, or originary, rate of interest which is determined in the general time market, that is, by the supply of present money (the money entrepreneurs spend in production processes) and the demand for present money - the money land and labor demand in production and the money businesses demand when they sell their products (Rothbard 1962, 375-89; 417-19). ${ }^{8}$ In the dynamic real 
world, of course, the natural rate of interest earned in a line of production is not equal to the pure rate as it also includes a specific entrepreneurial "risk" component and a general purchasing power component, both of which would be eliminated in the long run (Rothbard 1962, 550-52, 792-8). Moreover, capitalist-entrepreneurs' returns or price spreads are often greater than or less than the underlying natural rate as they earn profits and losses due to the general uncertainty of the marketplace. Capitalist-entrepreneurs earn profits when their rate of return is greater than the underlying natural interest rate, and earn losses when the opposite occurs (Mises 1949, 291; Rothbard 1962, 510-13). However capitalistentrepreneur arbitrage, which is shifting factors of production from lower return processes to higher return processes in order to earn profits, instills a tendency towards the wiping out of profits and losses that equalize the rates of return or price spreads so only the natural rate is earned, a tendency that is never reached because the data are always changing (Mises 1949, 293, 531, 533; Rothbard 1962, 371-2, 409-10, 511-12, 625-6).

The coordinating role of profits and losses cannot be overemphasized. The lodestar in allocating scarce means among competing ends in a modern economy is economic calculation. Economic calculation is monetary calculation, or estimating the value of resources according to the monetary returns they can earn in various production processes. In the market economy qualitative consumer values are imputed into quantitative prices. Through their various purchases consumers send signals to producers about what they value highly and consequently what should and should not be produced. ${ }^{9}$ When resources are shifted from a less profitable venture to a more remunerative one, they are shifted from producing goods that consumers value less highly to producing goods that consumers value more highly. The opposite occurs for losses. A profit return is not just a return greater than costs, but also a return greater than the underlying natural interest rate, since this return represents the average rate the businesses could have earned by investing their money in another line of production, which is the opportunity cost.

The loan rate is simply a reflection of this more general and fundamental natural interest rate (Mises 1949, 524; Rothbard 1962, 379). In fact, the irrelevance of the loan market in determining the rate of interest can be seen by acknowledging that an economy without a loan market would still have interest expressed through the price spreads (Rothbard 1962, 425-6). The pure rate found in loan interest is not only mixed in with entrepreneurial risk and purchasing power components, but also potentially profit since this return is fixed at the time of the contract (Mises 1949, 455-6, 533, 536-42). As with the price spreads there prevails a tendency for the equalization of loan rates due to profit-seeking entrepreneurs. Individuals 
on the loanable funds market borrow and lend based on the estimated rates of return in the production structure. Borrowers will only borrow at an interest rate greater than or equal to the rate of return they plan on earning. Similarly, lenders will only lend at an interest rate greater than or equal to the rate of return they could earn by directly investing in a production process. When the natural rate rises, the loan rate rises; when the natural rate falls, the loan rate falls (Rothbard 1962, 420-41).${ }^{10}$ Clearly, the loan rate aids in determining the feasibility of various lines of production as they will be deemed profitable or unprofitable depending on whether or not their estimated return is greater than or less than the rate of interest, and businesses who need to borrow to embark upon the projects will only do so if the return is greater.

Moreover, in contrast to the Keynesians, the interest rate plays a coordinating role in the intertemporal allocation of resources according to consumer preferences due to its relationship with time preferences. Businesses are able to gauge the profitability of investments through present value discounting using the interest rate. When the factors of production are cumulatively priced less than the present value of a project, it is profitable to engage in; when they are priced more, it is not. The interest rate acts as a brake on the length of production processes, since the present value of long-term projects are affected more than short-term projects by changes in the interest rate (Mises 1949, 524, 529, 544; Rothbard 1962, $539,996)$. A lower interest rate is a reflection of lower time preferences and signifies that consumers are more willing to spend money on consumption in the future. As a result, long-term production processes are now more profitable to embark upon then before, which is reflected in the fact that present value discounting with the new rate of interest shows an increased profitability of long-term investments relative to short-term investments. Consequently, higher interest rates result in the adoption of more short-term processes.

These strictures bear emphasizing because the interest rate is often seen in the Keynesian framework as a parameter that the monetary authorities can costlessly change without any real effects on the capital structure of an economy. Moreover, not only is the coordinating role of interest rates neglected in Keynes's analysis but, more fundamentally, there is no reference to the natural rate of interest in the production structure as the true interest rate. Instead, the natural rate is referred to as the marginal efficiency of capital and the entire emphasis is on the loan rate of interest. ${ }^{11}$ Keynes in fact goes so far as to explicitly criticize Mises, as well as Hayek and Robbins, with confusing the two (Keynes 1936, 192-3). But Rothbard points out that the marginal efficiency of capital is actually the rate of interest, and that the loan rate only mirrors it (Rothbard 1962, 371-2). ${ }^{12}$ 
This Austrian point, which was continually emphasized by Rothbard in his various discussions of the Keynesian system (1962, 1963, 1992), constitutes an important Austrian critique. In fact, it will be shown that the reason for the liquidity trap is due to an expected rise not only in the loan rate but also in the natural rate, which is a necessary correction in order for the economy to get out of a depression. Rothbard spoke wisely when he said that "it is precisely this preoccupation with the relatively unimportant problems of the loan market that constitutes one of the greatest defects of the Keynesian theory of interest" (Rothbard 1962, 372).

\section{THE LIQUIDITY TRAP AND THE NEED TO LET MARKET FORCES WORK}

As discussed above, the speculative demand for money is a decreasing function of the rate of interest (the demand curve slopes downwards). Traditionally, an increase in the supply of money causes an excess supply of money which incentivizes individuals to buy bonds, which in turn pushes up their prices and lowers the interest rate, thereby increasing the quantity of money demanded. However, when the speculative demand for money is infinitely elastic (the demand curve is horizontal) at a given rate of interest, the economy is instead said to be in a liquidity trap. In this case, with the increased supply of money individuals will not spend it on bonds and will instead hoard the money. Individuals are said to not buy bonds because they are anticipating a fall in bond prices (a rise in the rate of interest), and are correspondingly holding back purchases. The increased supply of money does nothing, and interest rates do not fall to stimulate investment (Snowden and Vane 2005, 104-8, 118).

The problem with this theory is that it considers the loan rate of interest to be the rate of interest, when in reality the loan rate of interest is based on the natural rate of interest. The loan rate only increases if the natural rate also increases. The loan rate would not rise if the natural rate is expected to remain the same because it would not pay to borrow funds. Therefore, if individuals do not buy bonds because they are expecting bond prices to fall in the future (that is, they are expecting the loan interest rate to rise), then this is because individuals are expecting the natural rate to rise.

Austrians seek to explain depressions in price theoretic terms. Austrian Business Cycle Theory (ABCT) is neither a theory that is founded on non-economic assumptions about the volatility of human psychology and confidence nor a theory focusing on the movement of aggregate variables unconnected to human decision making. ABCT is instead a theory grounded in a microeconomic analysis of the consequences of 
the distortion of a functioning price system through the manipulation of money and credit. This theory holds that when a central bank expands the money supply to increase loans to businesses, it artificially lowers interest rates and sets in motion an unsustainable boom as the interest rates and the production structure are no longer based on time preferences. This includes not only the loan interest rate but also the natural rate. Under normal conditions, when time preferences fall there is a decrease in the consumption-investment proportion. The decreased consumption spending lowers the prices of factors in the stages closest to consumption, while the additional investment spending pushes up the prices of factors in the stages farthest from consumption (that is, long-term production processes). There is decreased profitability in the stages closest to consumption and increased profitability in those which are farthest away. As stated earlier, the loan interest rate often guides this process by increasing the profitability of more long-term projects through present value discounting. ${ }^{13}$ The result of this is, as a reflection of lower time preferences, to lower the natural rate of interest and consequently the loan rate of interest.

The same phenomenon with the natural rate occurs initially when increased bank credit substitutes for lower time preferences and pushes down the loan rate. Except for the important exception when consumption does not fall, increased investment pushes up the prices of capital goods and lowers the natural rate of interest. However, interest rates are artificially below what is supportable by time preferences. As time goes on and the public attempts to reassert its consumption-investment spending proportions, the natural rate rises as the price spreads increase from the increased consumption and decreased investment spending (Mises 2009 [1953], 362-3). The loan rate correspondingly rises as well. The crisis sets in as many of the recent additions to the capital stock are revealed to be not as profitable as businesses thought they would be, leading to a large burst of unemployed labor and capital goods in the overextended industries. In order for recovery to occur and resources be put back to work, the price of consumption goods relative to the price of capital goods must rise. This requires reductions in the prices of factors of production, particularly in the level of wages paid. ${ }^{14}$

In a depression, more than ever are profit and loss and adjustment in interest rates needed to guide entrepreneurial decisions to adjust prices and wages to the configuration of scarce societal resources required according to the new (and correct) consumer preferences. It was this mechanism that had been disrupted with the government-induced credit expansion. Neither expansionary fiscal nor monetary policy should be used, as expansionary fiscal policy in the form of deficit spending diverts savings and resources away from the productive sector, while expansionary monetary 
policy props up bad investments and may lead to another business cycle (Mises 1949, 792-4, 576-8; Rothbard 1962, 19-23).

In a depression the expected rise in the loan rate is a normal feature as it is based on the fact that the price spread between present and future goods will rise, which is an essential requisite for a market-based recovery. Thus, if businesses judge that their rates of return will rise in the future, barring an increase in spending this means that they expect prices of factors of production in the unprofitable industries to fall. When individuals expect that the price of a good will be lower in the future they withhold purchases and hoard money, decreasing their demand for those goods, which instills a lowering of prices in the present (Mises 1949, 566). The situation is no different for factors of production (Hutt 1954, 395). On the free market, prices, including wages, are relatively flexible downwards. ${ }^{15}, 16$

Therefore, when individuals hoard money, a fall in the necessary prices will soon follow. This will incentivize entrepreneurs to disgorge their cash balances and start investing again. Thus, the phenomenon of individuals not investing and instead building up their cash balances requires no "labyrinthine explanation" of a liquidity trap, as Rothbard describes it, but instead is just speculation that factor prices will fall, and actually helps speed up rather than inhibits the recovery process (Rothbard 1963, 40-41).

Why then do economies suffering under a liquidity trap not get out of it? This is because the loan rate does not rise since the natural rate does not rise because factor prices, particularly wages, do not fall. Interest rates also do not rise to the extent that governments conduct expansionary monetary policy to lower loan rates and pump money into the economy. Wages are rigid and not relatively flexible due to interventions such as governmentsupported unions, unemployment benefits, and mandated price ceilings (that is, the minimum wage). In addition, wages can also be rigid downwards to the extent that laborers are resistant because they expect that prices will rise in the future - that is, they have inflationary expectations. In addition, businessmen may be hesitant to invest in general because of "regime uncertainty," which is policy uncertainty about future government interventions that affect investors' private property (Higgs 1997; 2010). This greatly reduces the demand for factors and exacerbates the required fall in prices. Under such situations, wages do not fall enough and unemployment continues to persist. The price spread, moreover, does not rise and so the necessary corrections in the economy do not occur (Mises 1949, 566-7; Rothbard 1962, 790; 1963, 47-50).

Thus, the longstanding phenomenon that results in a stalled recovery described by a liquidity trap is not due to the demand for money being horizontal at a given interest rate, but instead is fundamentally due to rigidity of prices from government intervention that prevents necessary 
relative price adjustments to increase the price spread. The solution is not to engage in expansionary fiscal policy, which would serve to further misallocate resources, but instead to remove government-induced price rigidities and let the market adjust.

\section{CONCLUSION}

The liquidity preference theory of interest and the liquidity trap are critical concepts in understanding the Keynesian way of thinking about macroeconomic theory and policy. In a liquidity trap, the demand for money is infinitely elastic and interest rates do not fall because individuals speculate that they will rise in the future. Any explanation of the Keynesian Revolution would be incomplete without highlighting the role that liquidity traps play in the canonical model, and how that model was built to show that the market economy could not work on its own or even that monetary policy could not get economies out of depression. Instead, fiscal policy would be the only availability.

This chapter has argued the theory is wrong because it inappropriately suggests that the interest rate is determined by liquidity preference instead of time preference, and that it concentrates on the loan rate of interest instead of the natural rate of interest. The loan rate is only a reflection of the natural rate, which is found in the average rate of return or price spread in the economy. When individuals withhold purchases of securities because they expect the loan interest rate to rise in the near future, this means that the natural rate is expected to rise in the future. Investors' withholding of purchases of factors due to their anticipated fall sets processes in motion that lower their price in the present, which adjusts the price spread and allows for a market recovery to occur. The phenomenon of a liquidity trap only continues to persist and become a problem when prices, particularly wages, are propped up through government intervention.

\section{NOTES}

1. It should be noted that many of the technical terms and concepts in the Austrian theories discussed in this chapter are simplified for ease of readers' understanding without loss of the underlying arguments.

2. For a brief summary of other critical reviews of Keynes - such as from Pigou, Knight, Schumpeter, and Viner - see Harris (1947, 29-35).

3. To be fair, this is not saying that all earlier economists, or even the above writers, were purely laissez-faire theorists who argued that complete government nonintervention was the appropriate response to take in a depression (Blaug 1997, 644; Friedman 1969 [1967], 86-9). But it cannot be denied that the profession in general thought that 
Keynes's biggest influence was his attack on the self-correcting powers of the market, which he attributed to the older group of economists he called the "Classicals."

4. Friedman and Schwartz include the underemployment equilibrium and the liquidity trap as two of Keynes's unique and important challenges to orthodoxy (Friedman and Schwartz 1982, 41-2). Friedman notes that while Keynes's theory of interest and its relationship to the demand and supply of money was important, earlier quantity theorists had recognized the relationship between interest rates and the demand for money. Friedman considered Keynes's liquidity trap to be the distinctive difference between the two groups (Friedman 1969 [1966], 152). However, the earlier quantity theorists had never systematically integrated the relationship in their analysis (Blaug 1997, 618).

5. Related to the liquidity trap is the idea of the investment trap, in which investment spending is a decreasing function of the interest rate and is extremely inelastic, so even if interest rates could be lowered investment spending would not increase very much at all.

6. Krugman (1999, 20-21) considers the idea that depressions are the inevitable consequences of previous manipulations of money and credit that result in misallocations of resources as "fatalism." This is completely incorrect because the position is not one of pessimistic rigid determinism but instead one that emphasizes the amazing capacity of a free market economy to recalculate the use of scarce resources and reshuffle investment plans according to the changing constellation of consumer preferences.

7. Strictly speaking, the interest rate here is nominal, as it is the nominal interest rate that is the opportunity cost of holding money. However, for the purposes here it makes no difference to describe it as the interest rate, since in the Keynesian framework prices are sticky.

8. For a more in-depth analysis of the demand for present goods, see Newman (2014a).

9. The usefulness of profits and loss are especially important during a depression when various lines of production have been shown to be unprofitable and consequently there is a need to readjust the structure of production to consumer preferences. For more, see section 3 .

10. Contrary to Wicksell, when prices are stable this does not necessarily mean that the natural rate of interest is equal to the loan rate of interest (Hayek [2008] 1931, 213-21).

11. Strictly, the marginal efficiency of capital is the rate of discount that equalizes the sum of future earnings with the present price of an asset.

12. In a different context Rothbard $(1963,37)$ approvingly cited Hayek's review of Keynes's earlier work and emphasized that Hayek made this point to Keynes, that is, that the difference in the relative prices of capital goods in the stages of production represents the interest rate $(1931,434)$.

13. Often (but not always), the increased investment funds are first lent on the producer's loan market, and so the loan rate falls before the natural rate. But the increased funds are only absorbed by borrowers at a lower rate because they can now borrow more to invest in projects that were previously not profitable (since their rate of return was too low relative to the loan rate). The borrowers' investing of the funds sets in motion the process that lowers the natural rate. Therefore, the loan rate only falls in the present due to a fall in the natural rate in the future. The loan rate is still determined by the natural rate.

14. For a more in-depth analysis of ABCT as well as sources, see Newman (2014b, 476-9).

15. Of course, this is not to say that prices automatically and instantaneously adjust and all exchanges take place at equilibrium prices, but only that there is a tendency for prices to adjust based on the underlying supply and demand conditions. Moreover, often when prices are adjusting the underlying supply and demand conditions change, which sets in motion new equilibrium prices that markets tend towards.

16. The assertion that wages on the free market are flexible downward requires some backing up. This is not to deny that nominal wage rigidity appears to be a fundamental feature of modern market economies. However, the present authors argue that this rigidity is due fundamentally to government intervention in the economy (see below). 
Earlier, when governments intervened less, wages were not as rigid. In the United States from 1841 to 1891 , back when there was less government involvement and falling prices were the norm, wages were more flexible and did not show signs of downward rigidity (Hanes and James 2003, 1423; Hanes 2013, 123).

There have been papers that argue that nominal wage rigidity became a pervasive feature in the US economy starting in the 1890s (for example, Hanes 1993). These results are based on surveys collected by state governments during this time that appear to show that most businesses did not report wage cuts during the downturns in these years. However, the accuracy of the surveys can be questioned, and as a result they appear to overstate wage rigidity (O'Brien 2000). More research on the late nineteenth and early twentieth centuries should be conducted. For examples of wage flexibility during the 1870s and 1920-21 depressions, see Newman (2014b, 494-5; forthcoming, 30-33).

\section{REFERENCES}

Blaug, M. (2010 [1997]), Economic Theory in Retrospect, 5th edn, Cambridge: Cambridge University Press.

Friedman, M. (1969 [1966]), "Interest rates and the demand for money", in M. Friedman, The Optimum Quantity of Money and Other Essays, London: Macmillan.

Friedman, M. (1969 [1967]), "The monetary theory and policy of Henry Simons", in M. Friedman, The Optimum Quantity of Money and Other Essays, London: Macmillan.

Friedman, M. and Schwartz, A.J. (1982), Monetary Trends in the United States and the United Kingdom, Chicago: University of Chicago Press.

Garrison, R. (2006 [2001]), Time and Money: The Macroeconomics of the Capital Structure, New York: Routledge.

Hanes, C. (1993), "The development of nominal wage rigidity in the late 19th century", American Economic Review, 83 (4), 732-56.

Hanes, C. (2013), "Business cycles", in R. Parker (ed.), Routledge Handbook of Modern Economic History, New York: Routledge.

Hanes, C. and James, J.A. (2003), "Wage adjustment under low inflation: evidence from U.S. history", American Economic Review, 93 (4), 1414-24.

Harris, S. (1947), "Introduction: the issues", in S. Harris (ed.), The New Economics, London: Dennis Dobson Ltd.

Hayek, F. (2008 [1931]), "Prices and production", in F. Hayek and J. Salerno (eds), Prices and Production and Other Works, Auburn, AL: Ludwig von Mises Institute.

Hayek, F. (2008 [1931, 1932]), "Reflections on the pure theory of money of Mr. J.M. Keynes", in F. Hayek and J. Salerno (eds), Prices and Production and Other Works, Auburn, AL: Ludwig von Mises Institute.

Higgs, R. (1997), "Regime uncertainty - why the Great Depression lasted so long and why prosperity resumed after the war", The Independent Review, 1 (4), $561-90$.

Higgs, R. (2010), "Recession and recovery - six fundamental errors of the current orthodoxy", The Independent Review, 14 (3), 465-72.

Hutt, W.H. (2009 [1954]), "The significance of price flexibility", in H. Hazlitt (ed.), The Critics of Keynesian Economics, Auburn, AL: Ludwig von Mises Institute. 
Keynes, J.M. (1964 [1936]), The General Theory of Employment, Interest, and Money, London: Macmillan.

Knight, F. (1951), "The role of principles in economics and politics", American Economic Review, 41 (1), 1-29.

Knight, F. (2009 [1937]), "Unemployment: and Mr. Keynes's revolution in economic theory", in H. Hazlitt (ed.), The Critics of Keynesian Economics, Auburn, AL: Ludwig von Mises Institute.

Krugman, P. (2009 [1999]), The Return of Depression Economics and the Crisis of 2008, New York: Norton.

Mises, L. von (1990 [1932]), "The position of money among economic goods", in L. von Mises, Money, Method, and the Market Process, Norwell, MA: Kluwer Academic Publishers.

Mises, L. von (2006 [1928]), "Monetary stabilization and cyclical policy", in L. von Mises and P. Greaves (eds), The Causes of the Economic Crisis and Other Essays Before and After the Great Depression, Auburn, AL: Ludwig von Mises Institute.

Mises, L. von (2008 [1949]), Human Action, Auburn, AL: Ludwig von Mises Institute.

Mises, L. von (2009 [1953]), The Theory of Money and Credit, Auburn, AL: Ludwig von Mises Institute.

Modigliani, F. (2009 [1944]), "Liquidity preference and the theory of interest and money", in H. Hazlitt (ed.), The Critics of Keynesian Economics, Auburn, AL: Ludwig von Mises Institute.

Newman, P. (2014a), "Rothbard's time market and the demand for present goods", Quarterly Journal of Austrian Economics, 17 (1), 46-66.

Newman, P. (2014b), "The depression of 1873-1879: an Austrian perspective", Quarterly Journal of Austrian Economics, 17 (4), 474-509.

Newman, P. (forthcoming), "The depression of 1920-1921: a credit induced boom and a market based recovery?", Review of Austrian Economics.

O'Brien, A. (2000), "Were money wages always rigid? A look at the reliability of survey evidence on changes in wage rates", Industrial Relations: A Journal of Economy and Society, 39 (1), 48-61.

Rothbard, M. (1992), "Keynes, the man", in M. Skousen (ed.), Dissent on Keynes: A Critical Appraisal of Keynesian Economics, New York: Praeger.

Rothbard, M. (2008 [1963]), America's Great Depression, Auburn, AL: Ludwig von Mises Institute.

Rothbard, M. (2009 [1962]), Man, Economy, and State with Power and Market, Auburn, AL: Ludwig von Mises Institute.

Samuelson, P. (1947), "The general theory (3)", in S. Harris (ed.), The New Economics, London: Dennis Dobson.

Simons, H. (1936), "Keynes comments on money", The Christian Century, July, 1017.

Skousen, M. (2007 [1990]), The Structure of Production, New York: New York University Press.

Snowdon, B. and Vane, H. (2005), Modern Macroeconomics: Its Origins, Development and Current State, Cheltenham, UK and Northhampton, MA, USA: Edward Elgar Publishing.

Tobin, J. (1977), “How dead is Keynes?", Economic Inquiry, 15 (4), 459-68. 